\title{
Global climatology of surface water temperatures of large lakes by remote sensing
}

Article

Accepted Version

Layden, A., Merchant, C. and MacCallum, S. (2015) Global climatology of surface water temperatures of large lakes by remote sensing. International Journal of Climatology, 35 (15). pp. 4464-4479. ISSN 0899-8418 doi:

https://doi.org/10.1002/joc.4299 Available at https://centaur.reading.ac.uk/49732/

It is advisable to refer to the publisher's version if you intend to cite from the work. See Guidance on citing.

Published version at: http://onlinelibrary.wiley.com/doi/10.1002/joc.4299/abstract

To link to this article DOI: http://dx.doi.org/10.1002/joc.4299

Publisher: John Wiley \& Sons

All outputs in CentAUR are protected by Intellectual Property Rights law, including copyright law. Copyright and IPR is retained by the creators or other copyright holders. Terms and conditions for use of this material are defined in the End User Agreement.

www.reading.ac.uk/centaur 
Central Archive at the University of Reading

Reading's research outputs online 


\section{International Journal of Climatology}

\section{Global climatology of surface water temperatures of large lakes by remote sensing}

\begin{tabular}{|l|l|}
\hline List of Authors & Afiliations \\
\hline Layden, Aisling; & $\begin{array}{l}\text { The university of Edinburgh, } \\
\text { School of Geosciences, Crew Building, Kings Buildings, } \\
\text { West Main Rd, Edinburgh EH9 3JN }\end{array}$ \\
$\begin{array}{l}\text { A.Layden @ sms.ed.ac.uk } \\
\text { Phone: +44 (0) 131 650 5103 } \\
\text { FAX: +44 (0) 131 662 0478 }\end{array}$ \\
\hline $\begin{array}{l}\text { Merchant, } \\
\text { Christopher; }\end{array}$ & $\begin{array}{l}\text { Dept. of Meteorology, University of Reading } \\
\text { Harry Pitt Building, 3 Earley Gate, } \\
\text { PO Box 238, Whiteknights, Reading, RG6 6AL }\end{array}$ \\
\hline MacCallum, Stuart. & $\begin{array}{l}\text { The university of Edinburgh, } \\
\text { School of Geosciences, Crew Building, Kings Buildings, } \\
\text { West Main Rd, Edinburgh EH9 3JN }\end{array}$ \\
\hline
\end{tabular}

The authors gratefully acknowledge that this work is funded by the European Space Agency under contract 22184/09/I-OL. 


\section{Abstract}

Lake surface water temperatures (LSWTs) of 246 globally distributed large lakes were derived from Along-Track Scanning Radiometers (ATSR) for the period 1991 to 2011. The climatological cycles of mean LSWT derived from these data quantify on a global scale the responses of large lakes' surface temperatures to the annual cycle of forcing by solar radiation and the ambient meteorological conditions. LSWT cycles reflect the twice annual peak in net solar radiation for lakes between $1^{\circ} \mathrm{S}$ to $12^{\circ} \mathrm{N}$. For lakes without a lake-mean seasonal ice cover, LSWT extremes exceed air temperatures by $0.5^{\circ} \mathrm{C}$ to $1.7^{\circ} \mathrm{C}$ for maximum and $0.7^{\circ} \mathrm{C}$ to $1.9^{\circ} \mathrm{C}$ for minimum temperature. The summer maximum LSWTs of lakes from $25^{\circ} \mathrm{S}$ to $35^{\circ} \mathrm{N}$ show a linear decrease with increasing altitude; $-3.76 \pm 0.17{ }^{\circ} \mathrm{C} \mathrm{km}^{-1}\left(\mathrm{R}^{2}{ }_{a d j}=0.95\right)$, marginally lower than the corresponding air temperature decrease with altitude $-4.15 \pm 0.24{ }^{\circ} \mathrm{C} \mathrm{km}^{-1}\left(\mathrm{R}^{2}\right.$ adj $=$ 0.95). Lake altitude of tropical lakes account for $0.78-0.83\left(\mathrm{R}^{2}\right.$ adj $)$ of the variation in the March to June LSWT-air temperature differences, with differences decreasing by $1.9^{\circ} \mathrm{C}$ as the altitude increases from 500 to 1800 m.a.s.1..

We define an "open water phase" as the length of time the lake-mean LSWT remains above $4{ }^{\circ} \mathrm{C}$. There is a strong global correlation between the start and end of the lakemean open water phase and the spring and fall $0{ }^{\circ} \mathrm{C}$ air temperature transition days, $\left(\mathrm{R}^{2}{ }_{a d j}=0.74\right.$ and 0.80 respectively), allowing for a good estimation of timing and length of the open water phase of lakes without LSWT observations. Lake depth, lake altitude and distance from coast further explain some of the inter-lake variation in the start and end of the open water phase. 
Keywords:

Lake surface water temperature, climatology, air temperature, altitude, latitude

\section{Introduction}

Lakes act as integrators for the many factors affecting their temperature (Schneider et $a l ., 2009$ ), such as local climatic conditions (air temperature, wind speed and surface solar irradiance), with air temperature having most influence over lake ice cover (Livingstone and Adrian, 2009). The response of LSWTs to ambient air temperature is affected by geographical and physical factors such as lake altitude, continentality, depth (Brown and Duguay, 2010), the presence and extent of lake ice cover and inflow from streams and land run-off (Williams, 1965). Altitude and topography of high mountainous areas can promote distinctive weather patterns differentiating them from low-lying areas (Thompson et al., 2009). Altitude-dependent light intensity and quality can influence LSWTs (Wetzel, 1975). Continentality influences the interannual LSWT variability, with lakes relatively close to the coast showing considerably less variability due to the moderating oceanic effect (Thompson et al., 2009). The temporal and spatial extent of ice cover also has a feedback effect on the local climate through changes in albedo and heat flux (Williams and Stefan, 2006), with reduced ice cover resulting in increased evaporation (Brown and Duguay, 2010). There is a need for a global scale understanding of the climatic and lake characteristic drivers of LSWT climatology. 
The synoptic variability of air temperature is smoothed in the progression of lake temperature, due to the high effective heat capacity per unit area of lake water (Wetzel, 1975). This allows the frequency of global scale observations, available from remote sensing, to support a useful quantification of lake surface water temperature (LSWT) variability of resolvable lakes. Given climate change predictions of increases in the frequency and magnitude of air temperature extremes in the 21 st century (IPCC, 2012), determining the global scale response of LSWTs and the timing of ice phenology events (ice-on and ice-off dates) to ambient air temperatures is highly important. Ice phenology events are a good indicator of climate variability and climate change (Duguay et al., 2006) and have been considered for use as a climate index (Palecki and Barry, 1986; Lenormand et al., 2002).

To our knowledge, remotely sensed LSWTs have not been previously analysed on a global scale to explore their climatological behaviour and dependencies. There are some regional scale climatology studies, carried out using in situ data from numerous sources. Williams et al (2004) found that the timing of ice-off on 143 North American freshwater lakes (using linear regression), was more strongly related with the spring air temperature (mean air temperature from February to June), $\mathrm{R}^{2}=0.78$, than with latitude $\left(\mathrm{R}^{2}=0.59\right)$. The autumn air temperature (mean air temperature from September to December) and latitude explained a similar fraction of the variation in the timing of 0.73 and $0.71\left(\mathrm{R}^{2}\right)$, respectively. A consistent but weaker relationship was shown, between the ice phenology events and mean depth and surface area. This study also showed that a sliding mean air temperature for a fixed period before ice-on 
and ice-off were poor indicators of events. Lakes with an air temperature of $1{ }^{\circ} \mathrm{C}$ warmer were shown to cause later ice-on day, of $\sim 5$ days and an earlier ice-off day, of $\sim 6$ days. A follow-on study confirmed that the linear regression model best explained ice-off but that a log transform model best explained ice-on (Williams and Stefan, 2006). Many other smaller scale or regional studies show the response of ice-on and ice-off dates to various features in the air temperatures cycle. For 63 Finnish lakes lying between $60^{\circ}-70^{\circ} \mathrm{N}$, the mean temperature of individual months for up to five months before ice-on show significant correlation with ice-on timing. Regional variation, shown in the results of this study, was attributed to latitude and distance from coast (Palecki and Barry, 1986). A study on 196 Swedish lakes, spanning $13^{\circ}$ latitude, showed that ice-off had a nonlinear relationship with the mean annual air temperature (Weyhenmeyer et al., 2004). This possibly highlights regional differences, as a linear regression model was shown to best explain ice-off in North American lakes. Livingston (1999) found that the ice-off on Lake Baikal is related to both the mean air temperature during the thawing phase (April) and to the month of minimum temperature (February). Brown and Duguay (2010) suggest that the ice-on is dominantly controlled by summer and autumn air temperatures. Straskraba (1980) produced a parametric fit based on the annual surface temperature variations of 38 lakes of medium depth, spanning $0^{\circ}$ to $70^{\circ} \mathrm{N}$ at altitudes of $<2000$ m.a.s.1.. This model produced a good estimate of global LSWTs at low latitudes $\left(<30^{\circ} \mathrm{N} /{ }^{\circ} \mathrm{S}\right)$ when compared with observations from ARC-Lake (ATSR Reprocessing for Climate: Lake Surface Water Temperature \& Ice Cover. 
In these studies, comprising of LSWTs from different in situ sources, the inherent variation in the temporal and spatial LSWT resolutions may obscure the often subtle effects of lake characteristics on the LSWTs. Additionally, in these previous studies there is a wide variation in the range of air temperatures that best explain ice-on/iceoff; mean seasonal, mean of 1-5 preceding months and minimum month. The parametric model by Straskraba, driven by gradients in solar radiation for lakes of medium depth cannot be suitably used to assess the effect of varying lake characteristics on LSWT. The spatially resolved LSWT observations for a wide number of globally distributed lakes, which have been derived in a systematic manner, such as ARC-Lake observed LSWTs, has the potential to greatly add to understanding of the global LSWT climatological behaviour.

In this paper, we present a satellite-based climatology of LSWT of large lakes, including the geographical distributions of the annual cycle. The LSWT climatology is derived from Along-Track Scanning Radiometers (ATSR) observations as part of the ARC-Lake project (MacCallum and Merchant, 2012). We interpret the annual cycles of large lakes relative to the annual cycle in forcing of lakes from solar irradiance and ambient air temperature cycle, considering the effect of altitude on LSWTs and on ambient temperature.

For lakes that have a lake-mean seasonal ice cover, we present the climatological LSWT cold phase (the length of time the LSWT remains below $1{ }^{\circ} \mathrm{C}$ ), the LSWT open water phase (the length of time the LSWT remains above $4{ }^{\circ} \mathrm{C}$ ) and the warming and 
cooling intervening phases (the length of time taken for the LSWT to warm from $1{ }^{\circ} \mathrm{C}$ to $4{ }^{\circ} \mathrm{C}$ and to cool from $4{ }^{\circ} \mathrm{C}$ to $1{ }^{\circ} \mathrm{C}$. The inter-lake variability of the start and end of the phases are quantified through their dependency on the day the air temperature rises above $0{ }^{\circ} \mathrm{C}\left(0{ }^{\circ} \mathrm{C}\right.$ air warming day $)$ or on the day the air temperature falls below $0{ }^{\circ} \mathrm{C}(0$ ${ }^{\circ} \mathrm{C}$ air cooling day). We also attempt to explain more of the inter-lake variation of the start and end of the phases using lake physical characteristics; lake depth, surface area, altitude and distance from coast.

\section{Data source, lake distribution and salinity}

\subsection{Data source and validation}

Lake surface water temperatures (LSWTs) of 246 globally distributed large lakes. principally those with surface area $>500 \mathrm{~km}^{2}$ (Herdendorf, 1982; Lehner and Doll, 2004) were generated from the three ATSRs (ATSR1, ATSR2 and AATSR) (MacCallum and Merchant, 2012). The length of the time series varies for the 246 lakes, depending on instrument coverage. 119 lakes have continuous LSWT observations for 20 years (all three ATSR instruments, from August 1991 to December 2011), 113 have 16 years of continuous LSWT observations (2 ATSR instruments, from June 1995 to December 2011) and 14 lakes have 8-9 years of continuous LSWT observations (1 ATSR instrument). The ARC-Lake LSWT observations are available at http://datashare.is.ed.ac.uk/handle/10283/88 and are 
indexed according to surface area. Observations are made at a spatial resolution of $\sim 1$ $\mathrm{km}$ at nadir and averaged to $0.05^{\circ}$ cells $(\sim 5 \mathrm{~km})$. The narrow swath width of the ATSR instruments, provide high resolved (spatially) LSWT retrievals, but at relatively low temporal resolutions. The average temporal resolution of LSWT retrievals is $<1$ week. This prevents the diurnal variations being fully captured. However, the full resolution of $0.05^{\circ}$ cells which results in a possible 25 observations per cell, greatly increases the likelihood of LSWT retrieval, which is important in areas where cloud cover persists. Each $0.05^{\circ}$ cell has an uncertainty in the order of $0.4 \mathrm{~K}$ (relative standard deviation).

A target lake is identified on the basis of the geographical co-ordinates of a pixel in the ATSR imagery. A land/water mask (fixed in time) reconciling the global lakes and wetlands database (GLWD) polygon area and NAVOCEANO data was developed specifically to define lake boundaries used in the ARC-Lake project (MacCallum and Merchant, 2012). Valid LSWTs are estimated only for pixels that are effectively free from cloud (clear-sky). An algorithm based on Bayes' theorem (Merchant et al., 2008) is employed for assigning a clear-sky probability. The effectiveness of the lake product retrieval algorithms is assessed using two methods of data validation: analysis of the performance for case study images at full ATSR resolution and quantitative point comparisons with in situ observations. A match-up data set from in situ temperature data consisting of 52 observation locations covering 18 of the lakes was constructed. The majority of these lakes are located in North America or northern Europe but also include an African and Oceanic lake. The mean differences ranged 
between the instruments from $-0.34{ }^{\circ} \mathrm{C}$ to $-0.09{ }^{\circ} \mathrm{C}$ (day) and $-0.18{ }^{\circ} \mathrm{C}$ to $+0.06{ }^{\circ} \mathrm{C}$ (night) (MacCallum and Merchant, 2012).

The uncertainty in LSWT observations $(\sim 0.4 \mathrm{~K}$ per cell) is higher than for sea surface temperatures (SSTs) derived using ATSR instruments, $\sim 0.2 \mathrm{~K}$, primarily due to factors such as altitude, emissivity and continentality of air masses. LSWT retrieval uncertainties may be larger than the average uncertainty where cloud (and perhaps aerosols) are present or if there is failure in cloud detection. The relative sparseness of the validation match-up (between LSWT retrieval and in situ data) compared with SST match-up, prevents a reliable quantification of the cloud detection errors (MacCallum and Merchant, 2010).

At nighttime, the sub-micron surface (skin) temperatures (radiometric measurements) are generally cooler than the upper mixed layer temperature measured by in situ means. The biases associated with the skin effect for ATSRs are generally in the order of $0.2 \mathrm{~K}$ (Donlon et al., 2002). These biases can be greater in summer months where the skin effect is larger. The daytime variability in the solar radiation cycle introduces more variability in the daytime skin effect (Hook et al., 2003). Wind speed also has an effect, at wind speeds $>6 \mathrm{~m} / \mathrm{s}$, the skin effect is well characterised. At lower wind speeds, the skin effect shows greater variability, due to greater stratification (Donlon $e t$ al., 2002). The skin effect is systematic and it can be evident, even in data that are noisy, where the long term averages are considered. The bigger variability in the daytime skin effect is evident in the match-up of ATSR instrument and in situ 
temperatures. The daytime uncertainty is greater, $0.43 \mathrm{~K}(\mathrm{RSD})$, than the nighttime uncertainty, $0.33 \mathrm{~K}$, across the three instruments.

The observed lake-mean LSWT climatologies for large lakes, spanning latitudes from $55^{\circ} \mathrm{S}$ to $69^{\circ} \mathrm{N}$, are derived from the 0.05 degree data, over the available observation time period, averaging the daytime and nighttime observations. To fit the purpose of the different analyses, we use climatological data at a range of temporal resolutions; daily LSWTs (interpolated), twice a month LSWTs and monthly LSWTs. Figure 1 displays the location of the 246 lakes considered in this study, classified by surface area (obtained using polygon area in GLWD).

Throughout this study the dispersion of errors between lakes is characterised using \pm 2 standard deviations, giving a confidence level of $\sim 95 \%$. All regression values reported are $\mathrm{R}^{2}$ adj values (the ratio of the number observations to the number of predictors are considered) and are in decimal format.

\subsection{Global distribution of lake size and origin}

Lakes of known origin (ILEC, 1999; LakeNet, 2003) are categorized in terms of lake number and surface area for temperate and tropical lakes, Table 1 . The majority of lakes with unavailable lake origin ( $38 \%$ of lakes) are smaller lakes, accounting for only $11 \%$ of the total lake surface area. Almost two-thirds of all the observed large lakes are located between $40^{\circ} \mathrm{N}$ to $70^{\circ} \mathrm{N}$. The cluster of East African rift lakes make up a significant portion of the tropical lakes, Figure 1. Lake origin plays a significant part 
in the global distribution and surface area of large lakes. Tectonically formed lakes are globally well distributed, while glacial lakes exist mainly in temperate regions at latitudes above $40^{\circ} \mathrm{N}$. A small number of glacial lakes are found at equivalent latitudes in the southern hemisphere but are typically 5 times smaller in surface area. Table 1 highlights the surface area contribution that tectonic lakes make to the tropical large lakes (94\%). The importance of the tectonically formed Great African Lakes is evident both in terms of lake depth and area, accounting for six of the eight deepest tropical lakes.

\subsection{Lake salinity}

A total 64 of the 246 lakes are considered saline or a mix of saline and freshwater (S/F). Lakes with a total dissolved solids (TDS) content exceeding $3 \mathrm{~g} / \mathrm{l}$ are considered saline (Williams, 1962), although 6 of the 10 S/F lakes have a TDS of or below this value. The salinity values of these 64 lakes range from $0.5 \mathrm{~g} / \mathrm{l}$ for Lake Razelm (S/F) (Vadineanu et al., 1997) to $340 \mathrm{~g} / \mathrm{l}$ for the Dead sea (Horita, 2009). Over half of the saline and S/F lakes (36 of 64 lakes) are in Asia. The most saline of these Asian lakes (>155 g/l) are at altitudes in excess of 4000 m.a.s.l. or below sea level; Lake Karabogaz-gol (next to the Caspian sea) and the Dead sea are located at $22 \mathrm{~m}$ and $404 \mathrm{~m}$ below sea level respectively. In contrast, the most saline lake in Europe is Lake Manych-Gudilo, 42 g/l (Matishov et al., 2007), and the coastal lake of Bras d'Or with a salinity value of $25 \mathrm{~g} / \mathrm{l}$ is most saline North American lake. 


\section{Climatological characteristics}

We demonstrate the variation in the observed LSWT annual range and summer climatological LSWTs (temporal resolution of twice a month) with latitude on a global scale. The global distribution of the annual LSWT range, Figure 2, shows as expected, a strong relationship with latitude. Lakes from $23.5^{\circ} \mathrm{N}$ to $23.5^{\circ} \mathrm{S}$ have the lowest LSWT annual range, generally $<7.5^{\circ} \mathrm{C}$. The annual LSWT range widens with increasing latitude, peaking at latitudes of $45^{\circ}$ to $50^{\circ} \mathrm{N}$. Beyond $50^{\circ} \mathrm{N}$, a longer and more widespread seasonal freezing of lake surfaces causes a decrease in LSWT range. The variation in the LSWT range with latitude shows good consistency in North America and Europe. In Asia, the presence of high altitude lakes confounds the relationship between the LSWT range and latitude. All 13 lakes with altitudes exceeding 4000 m.a.s.1., are located in Asia between $29^{\circ}$ to $38^{\circ} \mathrm{N}$, Figure 2. While > 90\% of North American and European lakes are below 500 m.a.s.1., only 51\% of Asian lakes are below 500 m.a.s.l. Figure 3 shows the global distribution of summer LSWTs and the mean annual LSWT for the tropics $\left(23.5^{\circ} \mathrm{S}\right.$ to $\left.23.5^{\circ} \mathrm{N}\right)$, where the annual range is generally $<7.5^{\circ} \mathrm{C}$. Summer LSWTs, determined using July, August and September (JAS) LSWTs at latitudes $>23.5^{\circ} \mathrm{N}$ and January, February and March (JFM) LSWTs at latitudes $>23.5^{\circ} \mathrm{S}$ reflect the warmest months of the LSWT cycle, typically lagging the warmest months of the air temperature cycle by 1 month. Higher altitude lakes have lower summer LSWTs and lower mean LSWTs, as evident for high altitude Asian lakes and tropical lakes, Figure 3. From $23.5^{\circ} \mathrm{S}$ to $23.5^{\circ} \mathrm{N}$ the mean 
LSWT for lakes at altitudes $<1000$ m.a.s.l. range from $25.3^{\circ} \mathrm{C}$ to $29.9^{\circ} \mathrm{C}$. Within this region, higher altitude lakes have lower mean LSWTs. For example, Lake Tana at 1786 m.a.s.l., Lake Poopo at 3679 m.a.s.l. and Lake Titicaca, at 3827 m.a.s.l. have respective mean LSWTs of $21.9^{\circ} \mathrm{C}, 13.4{ }^{\circ} \mathrm{C}$ and $12.6{ }^{\circ} \mathrm{C}$, Figure 3.

\section{$4 \quad$ LSWT Climatological assessment}

Figures $4 \mathrm{a}$ and $4 \mathrm{~b}$ show the observed annual LSWT cycle (temporal resolution of twice a month) for lakes at altitudes $<2000$ m.a.s.1. $(n=231)$ in latitudinal zones of $10^{\circ}$ (for example, the $20^{\circ} \mathrm{S}$ zone is an average of LSWTs from $15^{\circ}$ to $25^{\circ} \mathrm{S}$ ) thereby summarizing much of the information in previous figures. Throughout the annual cycle, LSWTs in temperate regions in both hemispheres decrease with increasing latitude and have a higher LSWT range than in equatorial and high latitude regions, Figure $4 \mathrm{a}$ and $4 \mathrm{~b}$. Lakes from $45^{\circ} \mathrm{N}$ (from the $50^{\circ} \mathrm{N}$ latitudinal zone) northward generally remain frozen for several months of the year. Within the latitudinal zones 0$50^{\circ}$, the mean annual LSWT decreases with latitude at a rate of $0.44 \pm 0.02{ }^{\circ} \mathrm{C}$ per $1^{\circ}$ latitude in the northern hemisphere $\left(\mathrm{R}^{2}{ }_{a d j}=0.91\right)$ and at similar a rate of $0.40 \pm 0.04{ }^{\circ} \mathrm{C}$ per $1^{\circ}$ latitude in the southern hemisphere $\left(\mathrm{R}^{2} a d j=0.93\right)$. No large lakes exist from $19^{\circ}$ $\mathrm{S}$ to $31^{\circ} \mathrm{S}$, contributing to the large difference in the $20^{\circ} \mathrm{S}$ and $30^{\circ} \mathrm{S}$ minimum LSWT (July), Figure $4 \mathrm{~b}$. There is also a notable difference between the $20^{\circ} \mathrm{N}$ and $30^{\circ} \mathrm{N}$ minimum LSWT (January): there are 11 lakes in the $30^{\circ} \mathrm{N}$ zone, 6 of which are located in eastern Asia (China and Japan). Harsher winters in this region result in a minimum 
LSWT $\sim 13{ }^{\circ} \mathrm{C}$ lower than North American lakes at the same latitude, decreasing the overall mean minimum LSWT in the $30^{\circ} \mathrm{N}$ zone, Figure $4 \mathrm{a}$.

The thermal behaviour of a lake is a response to gains and losses of energy from all sources. For most lakes, the majority of the heat transfer occurs at the surface. The lake surface energy flux is a sum of the radiative components, latent and sensible heat fluxes, and heat transport by advection, as shown by;

$$
\Phi_{\text {net }}=\Phi_{\text {netSSI }(\downarrow)}+\Phi_{\text {long_in }}-\Phi_{\text {long_out }}+\Phi_{\text {lat }(\downarrow \uparrow)}+\Phi_{\text {sen }(\downarrow \uparrow)}+\Phi_{\text {adv }(\downarrow \uparrow)}
$$

where;

$\Phi_{\text {net }}=$ surface energy flux

$\Phi_{\text {netSSI }}=$ net surface solar $($ shortwave $)$ irradiance

$\Phi_{\text {long_in }}=$ thermal emission from clouds and the atmosphere into the lake

$\Phi_{\text {long_out }}=$ emissivity at the surface water

$\Phi_{\text {lat }}=$ latent heat fluxes; energy absorbed during phase changes in evaporation and ice melt and released in condensation and ice formation

$\Phi_{\text {sen }}=$ sensible heat fluxes; energy lost and gained by conduction and convection.

$\Phi_{\mathrm{adv}}=$ heat transport by advection

For a typical lake with a strong seasonal cycle, heat gains, resulting from the increasing solar radiation in early spring and into the summer, cause rapid heating of the upper layers. The rate of surface heating is generally much greater (wind dependant) than the rate of heat transfer from the upper mixed layer to the lower layers, as a result the thermocline is formed. The thermocline is reinforced by the exponential absorption of the solar radiation with depth. At the end of the summer/ early autumn, the decreasing incoming radiation and the resulting increase in evaporation, cause the lake to change from having net gain in energy to a net loss. At 
this time, the lake surface water begins to cool, becoming denser. The cooling water sinks and erodes the thermocline. Much of the LSWT response can be explained by netSSI, as shown in the following subsections.

\subsection{LSWT responses to solar radiation}

Air temperature, determined by the exchange of radiant energy between the sun, the earth's surface and the atmosphere, is driven by solar radiation, the principal source of energy to the earth's surface (Ritter, 2006). LSWTs exhibit some degree of variation that corresponds to the seasonal cycle of solar radiation at a given latitude (Lerman et $a l ., 1995)$. This is evident from the broad similarity, with time lag, of the hemispheric annual LSWT cycle (Figure 4a and 4b) and the hemispheric netSSI climatology (Figure $4 \mathrm{c}$ and $4 \mathrm{~d}$ ). The incoming and reflected monthly shortwave radiation data is sourced from the Energy Balanced and Filled (EBAF) data set (resolution $1^{\circ}$ x $1^{\circ}$ ) from the Clouds and the Earth's Radiant Energy System (CERES) project (Loeb et al., 2009).

\subsubsection{LSWT and solar radiation extremes}

The minimum netSSI (at the lake centre grid references of all lakes $<2000$ m.a.s.l.) is strongly correlated with latitude throughout both hemispheres; decreasing with increasing latitude at a marginally higher rate in the southern hemisphere, $5.1 \pm 0.3$ $\mathrm{W} / \mathrm{m}^{2}$ per $1^{\circ}$ latitude than in the northern hemisphere; $4.8 \pm 0.1 \mathrm{~W} / \mathrm{m}^{2}$ per $1^{\circ}$ latitude $\left(\mathrm{R}^{2}{ }_{a d j} \geq 0.96\right)$. Similarly, the corresponding minimum LSWT decreases at a rate of $0.46 \pm 0.04{ }^{\circ} \mathrm{C}$ per $1^{\circ}$ latitude $\left(\mathrm{R}^{2}{ }_{\text {adj }}=0.94\right)$ in the southern hemisphere and $0.44 \pm 0.03$ 
${ }^{\circ} \mathrm{C}$ per $1^{\circ}$ latitude $\left(\mathrm{R}^{2} a d j=0.79\right)$ in the northern hemisphere. Consequentially, there is a strong correlation between the monthly minimum netSSI $\left(>60 \mathrm{~W} / \mathrm{m}^{2}\right)$ and minimum LSWT in both hemispheres $\left(\mathrm{R}^{2} a d j \geq 0.88\right)$, for lakes $<2000$ m.a.s.l., as shown in Table 2. From $45^{\circ} \mathrm{N}$ northwards, the minimum netSSI decreases to below $60 \mathrm{~W} / \mathrm{m}^{2}$, at which point the lake-mean LSWT approaches $\sim 0{ }^{\circ} \mathrm{C}$, confounding the relationship between minimum netSSI and minimum LSWT. Globally and regionally, the minimum monthly netSSI of seasonally ice covered lakes are well correlated with the length of the cold phase, explaining $0.73\left(\mathrm{R}^{2}{ }_{a d j}\right)$ of the variation in North America lakes (93 lakes) while latitude explains 0.67.

The maximum netSSIs are poorly correlated with the maximum LSWTs in both hemispheres. As shown in Figure 4c and 4d, while the maximum netSSI show little changes with latitude, the length of the time of insolation levels close to the maximum netSSI decreases with increasing latitude. This directly affects the amount of heat absorbed through the lake surface in summer. As a result, the variation in the maximum LSWTs is better explained by latitude, 0.67 in the northern hemisphere and 0.82 in the southern hemisphere, as evident from Figure $4 \mathrm{a}$ and $4 \mathrm{~b}$.

\subsubsection{LSW response to equatorial insolation cycle}

Between latitudes of $5^{\circ} \mathrm{S}$ and $10^{\circ} \mathrm{N}$, top of atmosphere (TOA) solar radiation peaks twice a year, exhibiting two solar maxima and minima. The maxima occur towards the end of March and the end of September and the deeper minimum occurs during the 
hemispheric winter (Lewis, 1987). Lewis determines the hemispheric divide to be at $3.4^{\circ} \mathrm{N}$, the latitude at which the annual range of monthly TOA irradiance is at a minimum. The annual cycle of the total incoming shortwave solar radiation at all observed lake locations (21 lakes) within this range show the presence of two annual solar maxima and minima, the timing of the maxima ( \pm 1 month), and the occurrence of the deeper minimum in the hemispheric winter (considering the hemispheric divide to be at $3.4^{\circ} \mathrm{N}$ ). In further agreement with Lewis (1987), the annual range of incoming solar radiation is at a minimum for lakes closest to the hemispheric divide and increases at lake locations to the north and south.

Considering the reduction of shortwave radiation to the earths' surface due to cloud cover, which varies greatly depending on time of year and latitude, the two annual peaks in netSSI extremes are present at lake locations between latitudes from $9^{\circ} \mathrm{S}$ and $12^{\circ} \mathrm{N}$ but with varying amplitude. The range of annual netSSI varies across these locations and is at a minimum at $2^{\circ} \mathrm{S}$, south of which the deeper minimum netSSI generally occurs during the southern hemispheric winter. Northwards of $2^{\circ} \mathrm{S}$ it occurs in either hemispheric winter and the first annual maximum is dominant over the second maximum. The twice annual netSSI peaks are reflected in the LSWT cycle of all lakes $(\mathrm{n}=16)$ from $1^{\circ} \mathrm{S}$ to $12^{\circ} \mathrm{N}$, with the first annual maximum dominating the second annual maximum in 14 of the 16 lakes. The LSWT annual cycle for six lakes spaced throughout this region (from $1^{\circ} \mathrm{S}$ to $12^{\circ} \mathrm{N}$ ) and the netSSI cycle at the corresponding latitude are shown in Figure 5. As expected, the LSWT maxima and minima lag the netSSI maxima and minima. With an optimal lag (ranging from 2 
weeks - 6 weeks) applied to each lake, the variation in the netSSI cycle explain 0.76$0.97\left(\mathrm{R}^{2} a d j\right)$ of the variation in the LSWT cycle for 5 of the 6 lakes, as shown in Figure $5 \mathrm{~b}$ and $5 \mathrm{~d}$. The LSWT cycle for Lake Turkana shows poor correlation with the netSSI cycle. The range in the annual monthly LSWTs is at a minimum at $2^{\circ} \mathrm{S}$, reflecting that of the minimum netSSI range.

\subsubsection{Timing of peak LSWT}

The timing of the netSSI extremes are determined from the calculated TOA daily solar heat flux at every $1^{\circ}$ latitude and CERES 5-year reflected TOA shortwave radiation climatology (interpolated from monthly to daily). LSWT extreme timings extracted from the lake-mean daily climatological data are compared with the netSSI extreme timings to determine the LSWT/netSSI lag at each latitudinal band.

The range in latitude over which a true LSWT/netSSI lag can be defined is limited to lower temperate regions where there is a strong seasonal cycle but no seasonal ice cover (non-seasonally ice covered lakes $>25^{\circ} \mathrm{N} / \mathrm{S}, 38$ lakes). The predominately Mediterranean climate at lake locations $35^{\circ}$ to $55^{\circ} \mathrm{S}$, is considerably milder than the harsher moist continental climate from $35^{\circ}$ to $55^{\circ} \mathrm{N}$ (Strahler and Strahler, 1989). This allows for a greater range of southern hemispheric latitudes over which a true LSWT/netSSI lag can be defined. Figure 6 shows a 38 day and 43 day increase in the minimum and maximum LSWT/netSSI lag from the $30^{\circ}$ to $50^{\circ} \mathrm{S}$ latitudinal zones. 
There is a 23 day increase in the minimum lag between the $30^{\circ}$ and $40^{\circ} \mathrm{N}$ latitudinal zones, and no increase in the maximum lag, Figure 6.

\section{$5 \quad$ LSWT and air temperature relationship}

In this section, we consider the effect that latitude has on the relationship between monthly LSWT and air temperature climatological extremes. We use air temperature from the CRU_3.1_TS (Jones and Harris, 2008) data set, from January 1992 to December $2009\left(0.5^{\circ} \times 0.5^{\circ}\right.$ resolution $)$ at the lake centre grid references, collapsed into a monthly climatology.

The relationship between the LSWT and air temperature extremes from $60^{\circ} \mathrm{S}$ to $70^{\circ} \mathrm{N}$ (adjusted for altitude), is shown in $10^{\circ}$ latitudinal zones Figure 7.

The The altitude adjustment is applied to LSWT and air temperature extremes (with exception to the minimum LSWT of lakes with seasonal ice cover) on the basis of a strong correlation between maximum temperature (air and LSWT) and altitude, over latitudes from $25^{\circ} \mathrm{S}$ to $35^{\circ} \mathrm{N},(\mathrm{n}=66)$, The adjustment is applied at a rate of $-4.15^{\circ} \mathrm{C}$ $\mathrm{km}^{-1}\left(\mathrm{R}_{a d j}^{2}=0.95\right)$ for air temperature and $-3.76{ }^{\circ} \mathrm{C} \mathrm{km}^{-1}\left(\mathrm{R}^{2} a d j=0.95\right)$ for LSWT, as shown in Figure 8. The spread of errors (between lakes, $2 \sigma$ ) associated with these adjustments are \pm 0.23 and $\pm 0.17^{\circ} \mathrm{C} \mathrm{km}^{-1}$ respectively.

Although based on a limited region and considers only maximum LSWTs, this adjustment fulfills the purpose of minimizing the effect of altitude on LSWTs, allowing for a clearer view of the LSWT and air temperature relationship with latitude. 
Furthermore, lakes outside this zone are of low altitude, averaging $<500$ m.a.s.l. and therefore will not be substantially affected by the adjustment.

The LSWT extremes are warmer than the air temperature extremes, in latitudinal zones $40^{\circ} \mathrm{S}$ to $40^{\circ} \mathrm{N}$, Figure $7 \mathrm{a}$. The maximum LSWT exceeds the air temperature by $0.7{ }^{\circ} \mathrm{C}$ to $2.9^{\circ} \mathrm{C}$ across this region. The corresponding minimum temperature range is considerably greater due to seasonal ice cover at higher latitudes. Across latitudinal zones where minimum LSWTs generally remain above freezing (from $40^{\circ} \mathrm{S}$ to $30^{\circ} \mathrm{N}$ ), the LSWT and air temperature extreme differences are similar; $1.2^{\circ} \mathrm{C}$ to $2.9^{\circ} \mathrm{C}$ for maximum temperature and $1.4{ }^{\circ} \mathrm{C}$ to $3.0{ }^{\circ} \mathrm{C}$ for minimum temperature.

\subsection{LSWT and air temperature adjustment for altitude}

An LSWT lapse rate (the rate of decrease of temperature with increase in altitude) of $4.3{ }^{\circ} \mathrm{C} \mathrm{km}^{-1}\left(\mathrm{R}^{2}=0.83\right)$ determined for 161 lakes of Papua New Guinea, ranging from 0-3800 m.a.s.1. (Vyverman and Sabbe, 1995), compares well with LSWT adjustment rate used in this study. A study on small temperate lakes clustered on the Swiss Plateau yielded lapse rates of $3.7-5.5^{\circ} \mathrm{C} \mathrm{km}^{-1}$ (Livingstone and Lotter, 1998) and up to $6.9^{\circ} \mathrm{C} \mathrm{km}^{-1}$ in July (Livingstone et al., 1999). The higher lapse rates may be attributable to lake size. The large lakes in the global dataset appear to be less strongly coupled to the air temperature lapse rate $\left(6.5^{\circ} \mathrm{C} \mathrm{km}^{-1}\right)$ than the Swiss plateau lakes. 


\subsection{LSWT-air temperature difference with altitude}

With the applied altitude adjustment, across latitudinal zones, from $40^{\circ} \mathrm{S}$ to $30^{\circ} \mathrm{N}$, the LSWTs exceed the air temperatures by a difference of $0.5^{\circ} \mathrm{C}$ to $1.7^{\circ} \mathrm{C}$ for maximum temperature, by $0.7^{\circ} \mathrm{C}$ to $1.9^{\circ} \mathrm{C}$ for minimum temperature. Without the applied altitude adjustment, the difference is larger; $1.2^{\circ} \mathrm{C}$ to $2.9^{\circ} \mathrm{C}$ for maximum temperature and $1.4{ }^{\circ} \mathrm{C}$ to $3.0{ }^{\circ} \mathrm{C}$ for minimum temperature, indicating that the temperature decrease with altitude is greater for air temperature than for LSWT.

At 500 m.a.s.1., the LSWT-air temperature difference is demonstrated to be greater by $1.9^{\circ} \mathrm{C}$ than at 1800 m.a.s.l.. This assessment is based on lakes where the maximum LSWT and air temperatures are unaffected by latitude and where lake and air temperature altitudes are within 5\% of each other. For the 6 lakes meeting these conditions (ranging from $12^{\circ} \mathrm{S}$ to $20^{\circ} \mathrm{N}$ ), a strong LSWT-air temperature difference and altitude relationship is observed from March to June and over the altitude range 500 to 1800 m.a.s.1.. Lake altitude accounts for $0.78-0.83\left(\mathrm{R}^{2} a d j\right)$ of the variation in the temperature difference, with differences decreasing by $1.9^{\circ} \mathrm{C}$ with increasing altitude from 500 to 1800 m.a.s.l.. The netSSI for most tropical lakes is at its maximum in March (Figure 4c and 4d and Figure 5a and 5c), indicating the relationship between LSWT-air temperature difference and altitude is strongest following maximum netSSI. Altitude explains 0.33 of the temperature difference in July (statistically insignificant, $p=0.14$ ) and remains $<0.10$ from August through to February (with exception to November). A slightly higher proportion of the variation is explained in November (0.20), possibly because this month follows the second annual netSSI maximum. A 
study carried out by Livingstone and Lotter (1998) on lakes in the Swiss Plateau (located at $\sim 47^{\circ} \mathrm{N}$ ), showed a similar decrease in the summer (June to September) LSWT-air temperature differences $\left(1.8^{\circ} \mathrm{C}\right.$ ) with increasing altitude (from 500 to 2000 m.a.s.1.).

Finally, the greater range in the LSWT and air temperatures in temperate regions of the northern hemisphere, as evident from Figure 7, is primarily due to regional climatic hemispheric differences in temperate regions. The average air temperature range of the lakes in the $35^{\circ}$ to $55^{\circ} \mathrm{S}$ zones $\left(\sim 7^{\circ} \mathrm{C}\right.$; predominately Mediterranean climate) is substantially less than the lakes in the $35^{\circ}$ to $55^{\circ} \mathrm{N}$ zones $\left(\sim 31^{\circ} \mathrm{C}\right.$; predominately Continental climate) (Strahler and Strahler, 1989). Thus, the observed temperate LSWT ranges are much lower in the Southern hemisphere. For example, for Lake Taupo, $39^{\circ} \mathrm{S}$ the observed LSWT range is $8.6^{\circ} \mathrm{C}$, while for Clear Lake and Walker Lake at $39^{\circ} \mathrm{N}$ the LSWT range is $17.4^{\circ} \mathrm{C}$ and $18.4^{\circ} \mathrm{C}$ respectively.

\section{The relationship of temperature dependent LSWT phases with air temperature and lake characteristics}

A typical seasonal cycle of lake-mean LSWT for a dimictic lake is shown in Figure 9. Here, new terminology is introduced that is used in the assessment of the timing of features of this seasonal cycle in relation to ambient $0{ }^{\circ} \mathrm{C}$ air temperature and lake characteristics. The seasonal cycle can be broken down into four phases: a cold phase and an open water phase, separated by two intervening phases (warming and cooling). 
As illustrated in Figure 9, the boundaries of these phases are defined by the day of the year on which the lake-mean LSWT transitions through $1{ }^{\circ} \mathrm{C}$ and $4{ }^{\circ} \mathrm{C}$. We term these dates as $1{ }^{\circ} \mathrm{C}$ and $4{ }^{\circ} \mathrm{C}$ warming and cooling days, collectively, termed as the LSWT phase transition days. We examine the timing of the phase transition days in relation to the day on which the air temperature rises above $0{ }^{\circ} \mathrm{C}$ in Spring $\left(0{ }^{\circ} \mathrm{C}\right.$ air warming day $)$ and drops below $0{ }^{\circ} \mathrm{C}$ in autumn $\left(0{ }^{\circ} \mathrm{C}\right.$ air cooling day). Collectively these are referred to as the air temperature transition days.

\subsection{LSWT phases of freshwater lakes}

Although the temporal frequency of satellite data is not high enough to precisely detect the first $0{ }^{\circ} \mathrm{C}$ day, interpolating to the $1{ }^{\circ} \mathrm{C}$ day is a more effective indicator of ice-on/off for lake-mean LSWTs of large lakes. Typically while much of a large lakes' surface may be frozen, some parts will freeze and thaw earlier or later or remain unfrozen, yielding a mean LSWT greater than $0{ }^{\circ} \mathrm{C}$, which may not be representative of the majority of the lake. For this reason, the cold phase is considered the period during which at least part of the lake surface is likely to be ice covered. The cold phase transition days ( $1{ }^{\circ} \mathrm{C}$ cooling and warming days) show a good consistency with in-situ measurements of ice-on and ice-off days for 21 Eurasian and North American lakes (Benson and Magnuson, 2000; Layman, 2001) at locations close to lake centre over a varying time-span from 1955-2004, Figure 10a and 10b. The observed $1{ }^{\circ} \mathrm{C}$ cooling and warming days for the 21 lakes are on average 3.3 and 2.0 days earlier than the average in-situ ice-on and ice-off days. 
During the open water phase (period where the lake-mean LSWT remains above $4^{\circ} \mathrm{C}$, Figure 9) the lake is considered to be completely ice free. A study on the Great lakes, showed that while both open water and ice are present within a lake, the range of surface temperatures will not normally exceed $4{ }^{\circ} \mathrm{C}$ (Reinart and Reinhold, 2008). The start of this phase follows spring turnover, where the increasing density of warming water (from $0{ }^{\circ} \mathrm{C}$ to $4{ }^{\circ} \mathrm{C}$ ) causes surface water to sink and mix with deeper waters, breaking up any remaining ice cover. When the LSWT cools to $4^{\circ} \mathrm{C}$ in autumn (the same temperature as the lake bottom), the absence of density difference induces autumn turnover. After turnover, the rate at which cooling and surface ice formation occurs is a function of the lake heat storage capacity, often showing a relationship with lake depth (Pour et al., 2012). During the open water phase, the mixing and stratification patterns are highly dependent on individual lake characteristics such as lake depth and surface area, lake location (latitude and altitude) (Lewis, 1983) and on other factors such as local wind conditions and salinity (Boehrer and Schultze, 2008). Lake morphometry is a factor in the ice-on/off timing as it affects wind fetch, water circulation and heat storage (Pour et al., 2012). The phase transition days were extracted from the daily climatological LSWT data.

Figure 11 displays the start and end of the cold phase for 160 seasonally ice covered lakes, spanning from $29^{\circ}$ to $69^{\circ} \mathrm{N}$. The lengthening of the cold phase (earlier $1{ }^{\circ} \mathrm{C}$ cooling day and later $1{ }^{\circ} \mathrm{C}$ warming day) with increasing latitude is evident in North American and European lakes, Figure 11a and 11b. The mild partly maritime climate has a shortening effect on the cold phase in northern Europe with later cooling dates 
and earlier warming dates than North American lakes at corresponding latitudes. Salinity lowers the temperature of maximum density and the temperature at which water freezes, changing the physical properties of water on which these lake phases are dependent. For example, water with a typical ocean salinity of 35 practical salinity units (psu, $\sim 35 \mathrm{~g} / \mathrm{l}$ ), freezes at $\sim-2{ }^{\circ} \mathrm{C}$ (Boehrer and Schultze, 2008), therefore it is not useful to use the $1{ }^{\circ} \mathrm{C}$ and $4{ }^{\circ} \mathrm{C}$ warming and cooling days to determine the cold water and open water phases for saline lakes. This analysis is applied only to freshwater lakes at low altitude. Omitting high altitude (> 700 m.a.s.l.) and saline lakes, the $1{ }^{\circ} \mathrm{C}$ cooling and warming days of lakes $(n=122)$ change with latitude at a similar rate; 2.2 \pm 0.6 days per $1^{\circ}$ latitude $\left(\mathrm{R}^{2}{ }_{a d j}=0.34\right)$ and $2.3 \pm 0.5$ days per $1^{\circ}$ latitude $\left(\mathrm{R}^{2}{ }_{\text {adj }}=0.40\right)$ respectively, increasing the length of the cold phase by $4.5 \pm 0.9$ days per $1^{\circ}$ latitude (0.42). Similarly, the length of the corresponding open water phase shortens by $5.2 \pm$ 0.9 days per $1^{\circ}$ latitude (0.55). Across the Northern hemisphere, there is approximately a 4 month period over which the cold phase starts $\left(1{ }^{\circ} \mathrm{C}\right.$ cooling day, beginning with Lake Garry, Canada, at $66^{\circ} \mathrm{N}$ on 6 October) and ends $\left(1{ }^{\circ} \mathrm{C}\right.$ warming day, beginning with the shallow $(0.5 \mathrm{~m})$ Lake Razelm, Europe, at $44.8^{\circ} \mathrm{N}$ on $\left.01 \mathrm{March}\right)$. The last lake in Europe to pass the $1{ }^{\circ} \mathrm{C}$ warming day, is Lake Pya at $66^{\circ} \mathrm{N}$ (16 May) and in North America, is Lake Payne, at $59.4^{\circ} \mathrm{N}$ (20 June). Although, at a higher latitude, Lake Pya has an earlier end to its cold phase by $\sim 1$ month, demonstrating the shorter cold phases of European lakes.

\subsection{Dependence of LSWT phases on air temperature}


The relationship between air temperature and ice-on/off dates is long established (Brown and Duguay, 2010) and statistically, air temperature can explain 60\% to $70 \%$ of the variance in ice-off (Livingstone and Adrian, 2009). We regress the $1{ }^{\circ} \mathrm{C}$ and $4{ }^{\circ} \mathrm{C}$ warming days with the $0{ }^{\circ} \mathrm{C}$ air warming day and the $1{ }^{\circ} \mathrm{C}$ and $4{ }^{\circ} \mathrm{C}$ cooling days with the $0{ }^{\circ} \mathrm{C}$ air cooling day for non-saline lakes $<700$ m.a.s.l. (122 lakes) globally and regionally (North America, Europe and Asia). As latitude is strongly related to air temperature and has been considered as a proxy for air temperature in many LSWT studies (Weyhenmeyer et al., 2004), we also regress the LSWT phase transition days with latitude. For this analysis, we assess daily T2 ( $2 \mathrm{~m}$ air temperature) climatological ECMWF re-analysis data (ECMWF, 2009), for the years 1991 to 2010, at grid references closest to the lake centre, applying a 14-day moving average. The regression equations (constant and air temperature day coefficient) reported in Table 3 to Table 6 are suitable for the prediction of the LSWT phases and phase transition days for large non-saline lakes < 700 m.a.s.l., in North America, Europe and Asia, lying within $42^{\circ}$ to $69^{\circ} \mathrm{N}$, within a surface area of 100 to $32,000 \mathrm{~km}^{2}$ and depths ranging from $<1-680 \mathrm{~m}$.

Globally, the air temperature transition days explain 0.65 and $0.60\left(\mathrm{R}^{2}{ }_{a d j}\right)$ of the interlake variation in the timing of the $1{ }^{\circ} \mathrm{C}$ cooling and warming days, Table 3 , whilst latitude explains only 0.34 and 0.40 of the variation. The length of time the air temperature remains below $0{ }^{\circ} \mathrm{C}$ explains 0.70 of the variance in the length of the cold phase whilst latitude explains only 0.42 . Similarly, for the timing of the $4{ }^{\circ} \mathrm{C}$ cooling and warming days, air temperature transition days explain more of the variation $\left(\mathrm{R}^{2}\right.$ adj 
$=0.74$ and 0.80$)$, Table 4 , than latitude (0.42 and 0.54). Air temperature explains 0.85 of the variance in the length of the open water phase whilst latitude explains only 0.55 . Air temperature explains more of the variation in the $4{ }^{\circ} \mathrm{C}$ days than the $1{ }^{\circ} \mathrm{C}$ days, as shown in Table 3 and Table 4 . This is owing to the presence of ice at the $1{ }^{\circ} \mathrm{C}$ lakemean value. At this lake-mean temperature, parts of the lake surface are ice free and responding to ambient air temperatures while other parts of lake remain ice covered. The extent of lake ice cover varies from lake to lake confounding the inter-lake relationship between the $1{ }^{\circ} \mathrm{C}$ days and air temperature. Additional factors during warming, such as the insulating effect of overlying snow, affects the timing of the ice melt (Dutra et al., 2010), further confounding the relationship with air temperature. As shown in Table 4, globally and regionally (with exception to Europe), air temperature shows a stronger relationship with the $4{ }^{\circ} \mathrm{C}$ warming day than the $4{ }^{\circ} \mathrm{C}$ cooling day. This is possibly because the rate of cooling can be highly dependent on the effective heat storage capacity of the lake. In Europe, air temperature explains a consistently low amount of the inter-lake variation in the timing of all 4 LSWT phase transition days $(0.30-0.32)$.

Regional differences are expected due to localized climate system and influences. For example, in North America the inflow of colder water due to ice melt at high latitudes, may affect the relationship between air temperature and the $1{ }^{\circ} \mathrm{C}$ and $4{ }^{\circ} \mathrm{C}$ warming days. Additionally, the limnic ratio, the ratio between the total lake area and the total documented regional area, expressed as a percentage (Lerman et al., 1995) varies regionally; $0.2 \%$ in Asia, $1.1 \%$ in Europe and $1.7 \%$ in North America. 


\subsubsection{Relationship of LSWT phases with lake physical characteristics}

Expanding the regression with air temperature to include distance from coast (Wessel and Smith, 1996) and lake physical characteristics (depth, altitude and surface area) obtained from Herdendorf (1982), Lehner and Doll (2004), the ILEC World Lake Database (http://wldb.ilec.or.jp/), LakeNet

(http://www.worldlakes.org/) and Kourzeneva et al. (2012), contributes a small but statistically significant improvement to the explanation of the global inter-lake variation in the timing of the LSWT phase transition days of the 122 lakes.

Regionally, statistically significant relationships with the LSWT phase transition days were found for depth but not for lake surface area, indicating that depth may be a more suitable characteristic for estimating the effective heat storage capacity. Lake depth explains a further 0.02-0.09 of the inter-lake variation in the LSWT phase transition days in North America, accounting for more of the variation in the cooling days (0.040.09) than the warming days (0.02-0.03). Similarly, in Europe depth accounts for more of the variation in the $1{ }^{\circ} \mathrm{C}$ and $4{ }^{\circ} \mathrm{C}$ cooling days (0.10-0.12) than in the $4{ }^{\circ} \mathrm{C}$ warming day (0.07). This demonstrates that the effective heat storage capacity of the lake is more strongly dependent on the rate of cooling than the rate of warming. Depth causes a later cooling day, of 2-4 days/10 $\mathrm{m}$ in North America and 5-8 days/10 m in Europe. In contrast, while lake depth does not explain any of the variation in the cooling days 
in Asia, it explains a further 0.09 in the $4{ }^{\circ} \mathrm{C}$ warming day. Its effect is small, causing later warming by $<0.5$ day $/ 10 \mathrm{~m}$.

Lake altitude explains a further 0.05 of the variation in the warming days in North America causing a later $1{ }^{\circ} \mathrm{C}$ warming day (3.5 days/ 100 m.a.s.1.) and $4{ }^{\circ} \mathrm{C}$ warming day (1.3 days/ 100 m.a.s.1.), across the range of altitudes, 0- 700 m.a.s.1, Table 5.

In Europe, distance from coast replaces air temperature in the stepwise regression for all four phase transition days, explaining more of the inter-lake variation (0.36-0.57) than air temperature (0.30-0.32). Opposite to what is expected, lakes further from the coast show a later $1{ }^{\circ} \mathrm{C}$ and $4{ }^{\circ} \mathrm{C}$ cooling day and an earlier $1{ }^{\circ} \mathrm{C}$ and $4{ }^{\circ} \mathrm{C}$ warming day (Table 5). Inland lakes have harsher winters due a greater distance from the moderating effect of the ocean (Thompson et al., 2009). Latitude, when added to the stepwise regression, also replaces distance from coast for all 4 transition days. This demonstrates that distance from coast in Europe mis-leadingly acts as a proxy for latitude and air temperature.

Other factors not considered here, such as, wind and snow depth are expected to affect the timing of the LSWT phase transition days. The mechanical action of wind can prevent the formation of solid ice cover on the initial ice skim. Wind also can accelerate ice-on by causing a greater rate of cooling and ice-off by breaking up ice and mixing it with warmer sub-surface water (Williams, 1965). Overlying snow will have insulating effect, affecting the timing of the ice melt (Dutra et al., 2010). 


\subsubsection{Warming and cooling intervening phases}

The cooling and warming intervening phase is the time taken for the LSWT to change between the cold and open water phases; to cool from $4{ }^{\circ} \mathrm{C}$ to $1{ }^{\circ} \mathrm{C}$ and warm from $1{ }^{\circ} \mathrm{C}$

to $4{ }^{\circ} \mathrm{C}$, Figure 9 . Globally and regionally (with exception to Europe) there is a stronger relationship between air temperature and the warming intervening phase than the cooling intervening phase (Table 6), again demonstrating the stronger relationship between air temperature and warming. Globally, the air temperature explains 0.16 $\left(\mathrm{R}^{2} a d j\right)$ of the variation in the length of the cooling intervening phase and 0.40 of the length of the warming intervening phases. Other than Asia, where air temperature and surface area explains 0.93 of the length of the warming intervening phase, the intervening phases are poorly explained by air temperature and lake characteristics. It is likely that the variations in the extent of lake ice cover at the $1{ }^{\circ} \mathrm{C}$ days, section 6.2 , confounds the relationship between air temperature transition days and the length of the two intervening phases.

\section{$7 \quad$ Summary and conclusions}

Global LSWT climatology has been explored using 20 years of satellite observations from ARC-Lake. These data were demonstrated through quantitative analysis to have an uncertainty of $\sim 0.4 \mathrm{~K}$ (MacCallum and Merchant, 2012). Within this study, LSWT climatologies have been used to quantify, on a global scale, the responses the annual 
cycle of large lakes' temperatures to the annual cycle of surface temperatures to the annual cycle of solar radiation and the ambient meteorological conditions. I find that the minimum monthly net solar shortwave irradiance (netSSI), for all lakes $<2000$ m.a.s.l., (which factors in the reduction of shortwave radiation to the earths' surface due to cloud cover in addition to seasonal Earth-Sun geometry), strongly predicts the minimum LSWTs and is a stronger predictor (than latitude) of different features in the LSWT annual cycle.

In North America, the minimum monthly netSSI explains slightly more of the interlake variation in the length of the cold phase (0.73) than latitude (0.67). Where the minimum monthly netSSI exceeds $60 \mathrm{~W} / \mathrm{m}^{2}$, it explains $0.88\left(\mathrm{R}^{2}{ }_{a d j}\right)$ of the variation in the minimum LSWT in the northern hemisphere and 0.90 in the southern hemisphere, Table 2 . At the minimum monthly netSSI value of $\leq 60 \mathrm{~W} / \mathrm{m}^{2}$, the minimum monthly LSWT is approximately $0{ }^{\circ} \mathrm{C}$, meaning that this threshold can be used to estimate if a lake has seasonal ice cover (lake-mean LSWT of below $1{ }^{\circ} \mathrm{C}$ for part of the cycle). The observed LSWT annual cycles with an optimal time lag were shown to be strongly related to the netSSI annual cycles in tropical lakes $\left(\mathrm{R}^{2}{ }_{a d j}=0.76-0.97\right)$, despite the small temperature variations and lack of seasonality. The twice annual netSSI peaks are reflected in the LSWT cycle of all lakes from $1^{\circ} \mathrm{S}$ to $12^{\circ} \mathrm{N}$, with the first annual netSSI and LSWT maximum, for most lakes, dominating the second annual maximum. Together these insights demonstrate how netSSI can be used to estimate several features of the LSWT cycle of lakes globally. 
Globally, considering all 246 lakes, the LSWT zonal (10 $)$ monthly extremes closely track air temperature extremes, Figure 7, with exception, as expected, to the minimum temperatures for seasonally ice covered lakes. The maximum LSWTs track maximum air temperatures more closely at higher altitudes. Across $10^{\circ}$ zones containing lakes without a seasonal ice cover period $\left(40^{\circ} \mathrm{S}\right.$ to $\left.30^{\circ} \mathrm{N}\right)$, the maximum LSWTs have a lower rate of change with altitude (by $0.39{ }^{\circ} \mathrm{C} \mathrm{km}^{-1}$ ) than maximum air temperature.

Changes in altitudes from 500 - 1800 m.a.s.l., were demonstrated to drive the changes in the maximum LSWT-air temperature difference of tropical lakes; decreasing by 1.9 ${ }^{\circ} \mathrm{C} \mathrm{km}{ }^{-1}$ with increasing altitude in the months from March $-\mathrm{June}\left(\mathrm{R}^{2}{ }_{a d j}=0.78-0.83\right)$. This period follows the timing of the first annual netSSI maximum (March) demonstrating that at higher altitudes, maximum LSWTs follow air temperature more closely. From July onwards, altitude explains $<0.10$ of LSWT-air temperature difference, with the exception of November. A slightly higher proportion of the variation is explained in November (0.20), possibly because this month follows the second annual netSSI maximum (lower in magnitude than the first netSSI maximum).

The typical annual LSWT cycle for dimictic lakes is defined by 4 phases (cold, openwater, and two intervening phases), the boundaries of which are marked by the days on which the LSWT passes through temperatures of $1{ }^{\circ} \mathrm{C}$ and $4{ }^{\circ} \mathrm{C}$, Figure 9 . The air temperature transition days are better estimators of the $4{ }^{\circ} \mathrm{C}$ cooling and warming days than of the $1{ }^{\circ} \mathrm{C}$ cooling and warming days, Table 3 and Table 4 . Although the lakemean $1{ }^{\circ} \mathrm{C}$ cooling and warming days show good consistency with in-situ 
measurements of ice-on and ice-off days, complications due to the presence and extent of ice at the $1{ }^{\circ} \mathrm{C}$ lake-mean boundary confound the relationship with air temperature. There is much regional variation in the response of the LSWT phase transition days and lake characteristics to the air transition days. This may be attributed to regional variation in the climate influences and in the limnic ratio.

Globally and regionally (with exception to Europe), the $0{ }^{\circ} \mathrm{C}$ air transition days explain 0.61-0.86 of the inter-lake variation in the $4{ }^{\circ} \mathrm{C}$ cooling and warming days and 0.22 0.71 of the $1{ }^{\circ} \mathrm{C}$ cooling and warming days. Globally and regionally (with exception to Europe), air temperature shows a stronger relationship with LSWT warming $\left(1{ }^{\circ} \mathrm{C}\right.$ and $4{ }^{\circ} \mathrm{C}$ warming days and the warming intervening phase $)$ than with LSWT cooling $\left(1{ }^{\circ} \mathrm{C}\right.$ and $4{ }^{\circ} \mathrm{C}$ cooling days and the cooling intervening phase), further supporting that lake warming is more strongly related with air temperature. In Asia and North America, air temperature also explains 0.85 and 0.45 of the variation in the length of the warming intervening phase and $<0.11$ of the variation in the length of the cooling intervening phase.

In Europe and North America, lake depth explains more of the inter-lake variation in the $1{ }^{\circ} \mathrm{C}$ and $4{ }^{\circ} \mathrm{C}$ cooling days than in the $1{ }^{\circ} \mathrm{C}$ and $4{ }^{\circ} \mathrm{C}$ warming days. In North America, depth explains 0.17 of the variation in the length of the cooling intervening phase and none of the variation in the length of the warming intervening phase, further supporting that lake-mean depth is a good indicator of the effective heat capacity of large lakes. 
In Europe, air temperature is a poor predictor of the phase transition days, explaining only $0.30-0.32$ of the inter-lake variation. Distance from coast replaces air temperature (and latitude) in step wise regression, shortening the length of the cold phase. Lakes further from the coast generally have a longer ice-cover period, indicating that distance from coast in Europe mis-leadingly acts as a proxy for latitude and air temperature.

The timing of the air temperature transition days closest to the lake centre grid references have proved to be a good measure in the estimation of the start, end and length of the cold phase and open water phase, both globally and regionally (Asia and North America), with exception to the $1{ }^{\circ} \mathrm{C}$ cooling day in Asia $\left(\mathrm{R}^{2}{ }_{a d j}=0.22 ; p=0.1\right)$. Although the phase transition day relationship is strengthened by the inclusion of lake characteristics, use of temperature alone allows for a simple but good estimation of the beginning and end of the open water and cold phase. Globally and regionally (Asia and North America), the $4{ }^{\circ} \mathrm{C}$ air temperature transition days have an approximate $1: 1$ relationship with the $4{ }^{\circ} \mathrm{C}$ phase transition days. Excluding the $1{ }^{\circ} \mathrm{C}$ cooling day in Asia, the air temperature and phase transition days show a similar 1:1 ratio relationship, explaining $0.58-0.71$ of the variation in the $1{ }^{\circ} \mathrm{C}$ phase transition days and 0.61-0.86 in the $4^{\circ} \mathrm{C}$ phase transition days. The equations outlined in Table 3 to Table 6 are suitable for the prediction of the LSWT transition days and phases of large nonsaline lakes $<700$ m.a.s.l. in North America, Europe and Asia, lying within $42^{\circ}$ to $69^{\circ}$ $\mathrm{N}$, with depths from $>1$ to $680 \mathrm{~m}$ and within surface areas of 100 to $32,000 \mathrm{~km}^{2}$. 
As demonstrated, remote sensing can be used to extend the reliable quantitative details of lake climatology beyond the information readily available from in situ data. Remote sensing also has the potential exists to address many more lakes in this way encompassing a larger portion of the earth's inland surface water.

As demonstrated, remote sensing can be used to extend the reliable quantitative details of lake climatology beyond the information readily available from in situ data. The potential exists to address many more lakes in this way encompassing a larger portion of the earth's inland surface water.

The ARC-Lake dataset is currently being extended to include $~ 1000$ of smaller lakes (surface area $>100 \mathrm{~km}^{2}$ ) worldwide using a temporally varying lake mask instead of the current temporally fixed lake mask.

This paper focused on interpretation of the LSWT climatologies. An analysis of the full time series of LSWTs should help refine the knowledge of the drivers of trends and inter-annual variability at global and regional scales. 


\section{$8 \quad$ References}

Ashton, G.D., 1986. River and Lake Ice Engineering. Water Resources Publication, Littleton, CO, USA.

Austin, J., Colman, S., 2008. A century of temperature variability in Lake Superior. Limnology and Oceanography 53:, 2724-2730. DOI:

2710.4319/lo.2008.2753.2726.2724.

Benson, B., Magnuson, J., 2000. Global lake and river ice phenology database, updated 2007. Boulder, CO: National Snow and Ice Data Centre/World Data Centre for Glaciology. Digital media.http://nsidc.org/data/lake_river_ice/freezethaw.html Accessed Nov 2011.

Boehrer, B., Schultze, M., 2008. Stratification of lakes. Rev. Geophys. 46:. AGU, p. RG2005. DOI: 2010.1029/2006rg000210.

Brown, L.C., Duguay, C.R., 2010. The response and role of ice cover in lake-climate interactions. Progress in Physical Geography 34:, 671-704. DOI:

610.1177/0309133310375653

Donlon, C. J., Minnett, P. J., Gentemann, C., Nightingale, T. J., Barton, I. J., Ward B. and Murray, M. J., 2002. Toward improved validation of satellite sea surface skin temperature measurements for climate research. Journal of Climate 15:, 353-369. DOI: 10.1175/1520-0442(2002)015<0353:TIVOSS > 2.0.CO;2

Duguay, C.R., Prowse, T.D., Bonsal, B.R., Brown, R.D., Lacroix, M.P., Menard, P., 2006. Recent trends in Canadian lake ice cover. Hydrological Processes 20:, 781-801. DOI: 710.1002/hyp.6131.

Dutra, E., Stepanenko, V.M., Balsamo, G., Viterbo, P., Miranda, P.M.A., Mironov, D., Schaer, C., 2010. An offline study of the impact of lakes on the performance of the ECMWF surface scheme. Boreal Environment Research 15:, 100-112.

ECMWF, 2009. European Centre for Medium-Range Weather Forecasts. ECMWF ERA-Interim Re-Analysis data, [Internet]. . NCAS British Atmospheric Data Centre. 2009-, Sep - Nov 2012. Available from

http://badc.nerc.ac.uk/view/badc.nerc.ac.uk_ATOM_dataent_1245 8543158227759. Accessed Sep - Nov 2012.

Gibbs, M., 2010. Lake Taupo long-term monitoring programme 2008-2009. National Institute of Water \& Atmospheric Research Ltd Hamilton.

Herdendorf, C.E., 1982. Large Lakes of the World. Journal of Great Lakes Research 8: 379-412.

Horita, J., 2009. Isotopic Evolution of Saline Lakes in the Low-Latitude and Polar Regions. Aquatic Geochemistry 15:, 43-69. DOI: 10.1007/s10498-10008-19050-10493. ILEC, 1999. World Lake Database. International Lake Environment Committee Foundation http://wldb.ilec.or.jp/ Accessed Mar - May 2011. IPCC, 2012. Summary for Policymakers. In: Managing the Risks of Extreme Events and Disasters to Advance Climate Change Adaptation. In: Field, C.B., Barros, V., Stocker, T.F., Qin, D., Dokken, D.J., Ebi, K.L., Mastrandrea, M.D., Mach, K.J., 
Plattner, G.-K., Allen, S.K., Tignor, M., Midgle, P.M. (Eds.), A Special Report of Working Groups I and II of the Intergovernmental Panel on Climate Change, pp. 1-19. Jones, P., Harris, I., 2008. CRU Time Series (TS) high resolution gridded datasets, [Internet].NCAS British Atmospheric Data Centre, . University of East Anglia Climatic Research Unit (CRU). April 2012 Available from

http://badc.nerc.ac.uk/view/badc.nerc.ac.uk__ATOM_dataent_1256 223773328276.

Kourzeneva, E., H. Asensio, E. Martin and S. Faroux, 2012. Global gridded dataset of lake coverage and lake depth for use in numerical weather prediction and climate modelling. Tellus Series a-Dynamic Meteorology and Oceanography 64.

LakeNet, 2003. LakeNet's global lake database. http://www.worldlakes.org Accessed Mar - May 2011.

Layman, K.L., 2001. The dependence of freshwater lake ice covers on climate, lake morphology, and geographic location. MS thesis , Univ. of Minnesota, Minneapolis (1955- 1996).

Lehner, B., Doll, P., 2004. Development and validation of a global database of lakes, reservoirs and wetlands. Journal of Hydrology 296:, 1-22. DOI:

10.1016/j.jhydrol.2004.1003.1028

Lenormand, F., Duguay, C.R., Gauthier, R., 2002. Development of a historical ice database for the study of climate change in Canada. Hydrological Processes 16:, $3707-$ 3722. DOI: 3710.1002/hyp.1235

Lerman, A., Imboden, D., Gat, J., 1995. Physics and Chemistry of Lakes. Springer, Verlag berlin Heidelberg.

Lewis, W.M., 1973. Thermal Regime of Lake Lanao (Philippines) and Its Theoretical Implications for Tropical Lakes. Limnology and Oceanography 18:, 200-217. Lewis, W.M., 1983. A revised classification of lakes based on mixing. Canadian Journal of Fisheries and Aquatic Sciences 40:, 1779-1787.

Lewis, W.M., 1987. Tropical Limnology. Annual Review of Ecology and Systematics 18:, 159-184.

Lewis, W.M., 1996. Tropical lakes: How latitude makes a difference. In: Schiemer, Boland (Eds.), Perspectives in Tropical Limnology. SPB Academic Publishers, Amsterdam, the Netherlands, pp. 43-64.

Livingstone, D.M., Adrian, R., 2009. Modeling the duration of intermittent ice cover on a lake for climate-change studies. Limnology and Oceanography 54:, 1709-1722. DOI: 1710.4319/lo.2009.1754.1705.1709

Livingstone, D.M., Lotter, A.F., 1998. The relationship between air and water temperatures in lakes of the Swiss Plateau: a case study with palaeolimnological implications. Journal of Paleolimnology 19:, 181-198. DOI:

110.1023/A:1007904817619

Livingstone, D.M., Lotter, A.F., Walker, I.R., 1999. The decrease in summer surf are water temperature with altitude in Swiss Alpine lakes: A comparison with air temperature lapse rates. Arctic Antarctic and Alpine Research 31:, 341-352. DOI:

$310.2307 / 1552583$ 
Loeb, N.G., Wielicki, B.A., Doelling, D.R., Smith, G.L., Keyes, D.F., Kato, S., ManaloSmith, N., Wong, T., 2009. Toward Optimal Closure of the Earth's Top-of-Atmosphere Radiation Budget. Journal of Climate 22:, 748-766. DOI:

710.1175/2008JCLI2637.1171.

MacCallum, S.N., Merchant, C.J., 2012. Surface Water Temperature Observations of Large Lakes by Optimal Estimation. Candian Journal of Remote Sensing 38:, 25-45. DOI: $10.5589 / \mathrm{m} 5512-5010$.

Magnuson, J.J., Robertson, D.M., Benson, B.J., Wynne, R.H., Livingstone, D.M., Arai, T., Assel, R.A., Barry, R.G., Card, V., Kuusisto, E., Granin, N.G., Prowse, T.D., Stewart, K.M., Vuglinski, V.S., 2000. Historical trends in lake and river ice cover in the Northern Hemisphere. Science 289:, 1743-1746. DOI:

1710.1126/science.1289.5485.1743

Matishov, D., Orlova, T., Gargopa, Y., Pavel'skaya, E., 2007. Long-term variability in the hydrochemical regime of the Manych-Chograi hydrological system. Water Resources 34:, 527-531. DOI: 510.1134/s0097807807050065.

Merchant, C.J., Llewellyn-Jones, D., Saunders, R.W., Rayner, N.A., Kent, E.C., Old, C.P., Berry, D., Birks, A.R., Blackmore, T., Corlett, G.K., Embury, O., Jay, V.L., Kennedy, J., Mutlow, C.T., Nightingale, T.J., O'Carroll, A.G., Pritchard, M.J., Remedios, J.J., Tett, S., 2008. Deriving a sea surface temperature record suitable for climate change research from the along-track scanning radiometers. Advances in Space Research 41:, 1-11. DOI: 10.1016/j.asr.2007.1007.1041.

Palecki, M.A., Barry, R.G., 1986. Freeze-up and Break-up of Lakes as an Index of Temperature-Changes during the Transition Seasons - a Case-Study for Finland. Journal of Climate and Applied Meteorology 25:, 893-902. DOI: 810.1175/15200450(1986)1025<0893:FUABUO>1172.1170.CO;1172.

Pour, H.K., Duguay, C.R., Martynov, A., Brown, L.C., 2012. Simulation of surface temperature and ice cover of large northern lakes with 1-D models: a comparison with MODIS satellite data and in situ measurements. Tellus Series a-Dynamic Meteorology and Oceanography 64:, DOI: 10.3402/tellusa.v3464i3400.17614

Reinart, A., Reinhold, M., 2008. Mapping surface temperature in large lakes with MODIS data. Remote Sensing of Environment 112:, 603-611. DOI:

610.1016/j.rse.2007.1005.1015.

Ritter, M.E., 2006. The Physical Environment: an Introduction to Physical Geography last updated 05 June 20012.

http://www.earthonlinemedia.com/ebooks/tpe_3e/title_page.html accessed 21 August 2012.

Schneider, P., Hook, S.J., Radocinski, R.G., Corlett, G.K., Hulley, G.C., Schladow, S.G., Steissberg, T.E., 2009. Satellite observations indicate rapid warming trend for lakes in California and Nevada. Geophysical Research Letters 36:, DOI: 10.1029/2009GL040846

Strahler, A.N., Strahler, A.H., 1989. Elements of Physical Geography. New York: John Wiley.

Straskraba, M., 1980. The Effects of Physical Variables on Fresh Water Production Analyses Based on Models. In: Le Cren, E.D., Lowe-Mcconnell, R.H. (Eds.), The 
Functioning of Freshwater Ecosystems. Cambridge University Press, Cambridge, pp. P13-84.

Thompson, R., Ventura, M., Camarero, L., 2009. On the climate and weather of mountain and sub-arctic lakes in Europe and their susceptibility to future climate change. Freshwater Biology 54:, 2433-2451. DOI: 2410.1111/j.1365-

2427.2009.02236.x.

Vadineanu, A., Cristofor, S., Ignat, G., Romanca, G., Ciubuc, C., Florescu, C., 1997. Changes and opportunities for integrated management of the Razim-Sinoe Lagoon System. International Journal of Salt Lake Research 6:, 135-144. DOI: 110.1007/bf02441890.

Vollmer, M.K., Bootsma, H.A., Hecky, R.E., Patterson, G., Halfman, J.D., Edmond, J.M., Eccles, D.H., Weiss, R.F., 2005. Deep-water warming trend in Lake Malawi, East Africa. Limnology and Oceanography 50:, 727-732. DOI:

710.4319/lo.2005.4350.4312.0727.

Vyverman, W., Sabbe, K., 1995. Diatom-Temperature Transfer-Functions Based on the Altitudinal Zonation of Diatom Assemblages in Papua-New-Guinea - a Possible Tool in the Reconstruction of Regional Paleoclimatic Changes. Journal of Paleolimnology 13:, 65-77. DOI 10.1007/BF00678111

Wessel, P., Smith, W.H.F., 1996. A global, self-consistent, hierarchical, high-resolution shoreline database. Journal of Geophysical Research-Solid Earth 101:, 8741-8743.

Wetzel, R., 1975. Limnology. Saunders college Publishing, Holt.

Weyhenmeyer, G.A., Meili, M., Livingstone, D.M., 2004. Nonlinear temperature response of lake ice breakup. Geophysical Research Letters 31:, DOI:

10.1029/2004GL019530

Williams, G.P., 1965. Correlating freeze-up and break-up with weather conditions.

Candian Geotechnical Journal II:, 313-326.

Williams, S.G., Stefan, H.G., 2006. Modeling of lake ice characteristics in North America using climate, geographyl, and lake bathymetry. Journal of Cold Regions Engineering 20:, 140-167. DOI: 110.1061/(ASCE)0887-1381X(2006)1020:1064(1140) Williams, W.D., 1962. A contribution to lake typology in Victoria, Australia. Int Ver Theor Angew Limnol Verh 15:, 158-168 


\begin{tabular}{|l|l|l|l|l|}
\hline \multirow{2}{*}{ Lake origin } & \multicolumn{2}{|l|}{$\begin{array}{l}\text { Temperate lakes, } \mathrm{n}=203 \\
\text { (of known origin, } \mathrm{n}=132)\end{array}$} & \multicolumn{2}{l|}{$\begin{array}{l}\text { Tropical lakes, } \mathrm{n}=42 \\
\text { (of known origin, } \mathrm{n}=19)\end{array}$} \\
\cline { 2 - 5 } & $\begin{array}{l}\text { Number } \\
\text { of lakes } \\
(\%)\end{array}$ & $\begin{array}{l}\text { surface area } \\
\text { of lakes } \\
(\%)\end{array}$ & $\begin{array}{l}\text { Number } \\
\text { of lakes } \\
(\%)\end{array}$ & $\begin{array}{l}\text { surface area of } \\
\text { lakes } \\
(\%)\end{array}$ \\
\hline $\begin{array}{l}\text { Coastal, Fluvatile } \\
\text { \& Volcanic }\end{array}$ & 11 & 4 & 35 & 6 \\
\hline Glacial & 72 & 82 & 0 & 0 \\
\hline Tectonic* & 17 & 14 & 65 & 94 \\
\hline
\end{tabular}

*excluding the Caspian Sea (as it accounts for one third of the surface area of all large lakes in this study)

Table $1 \quad$ Lake origin of temperate (132 lakes) and tropical lakes (19 lakes) in terms of their percentage of the total number and total surface of lakes, showing that tectonic lakes account for most of the surface area of tropical lakes of known origin

\begin{tabular}{lllllll}
\hline Variable & Region & $\begin{array}{l}\text { Number of } \\
\text { records }\end{array}$ & $\begin{array}{l}\mathrm{R}^{2} \\
\text { Adjusted }\end{array}$ & $\begin{array}{l}\text { Standard } \\
\text { error } \\
\left({ }^{\circ} \mathrm{C}\right)\end{array}$ & Constant & $\begin{array}{l}\text { Coefficient of } \\
\text { Variable } \\
\left({ }^{\circ} \mathrm{C} \mathrm{W} / \mathrm{m}^{2}\right)^{-1}\end{array}$ \\
\hline $\begin{array}{l}\text { Minimum } \\
\text { monthly } \\
\text { netSSI }\end{array}$ & $\begin{array}{l}\mathrm{NH} \\
\left(0^{\circ}-45^{\circ} \mathrm{N}\right)\end{array}$ & 61 & 0.88 & 3.9 & -7.37 & 0.121 \\
\cline { 2 - 7 } & $\begin{array}{l}\mathrm{SH} \\
\left(0^{\circ}-55^{\circ} \mathrm{S}\right)\end{array}$ & 31 & 0.90 & 3.1 & +1.94 & 0.086 \\
\hline
\end{tabular}

Table 2 Linear regression of minimum observed LSWT versus minimum netSSI for lakes $<2000$ m.a.s.l. where the minimum netSSI $>60 \mathrm{~W} / \mathrm{m}^{2}$ (from $0^{\circ}$ to $45^{\circ} \mathrm{N}$ and from $0^{\circ}$ to $55^{\circ} \mathrm{S}$ ), showing that the minimum monthly netSSI is a very strong predictor $\left(\mathrm{R}^{2}{ }_{a d j} \geq 0.88\right)$ of the variation in the minimum LSWTs 


\begin{tabular}{|c|c|c|c|c|c|c|c|}
\hline $\begin{array}{l}\text { Phase } \\
\text { transition } \\
\text { day }\end{array}$ & $\begin{array}{l}\text { Air } \\
\text { temperature } \\
\text { transition } \\
\text { day }\end{array}$ & Region & $\begin{array}{l}\text { Number } \\
\text { of lakes }\end{array}$ & $\begin{array}{l}\mathrm{R}^{2} \\
\text { Adjusted }\end{array}$ & $\begin{array}{l}\text { Standard } \\
\text { error } \\
\text { (days) }\end{array}$ & Constant & $\begin{array}{l}\text { Air } \\
\text { temperature } \\
\text { Transition day } \\
\text { coefficient } \\
\text { (days/day) }^{-1} \\
\end{array}$ \\
\hline \multirow{4}{*}{$\begin{array}{l}1{ }^{\circ} \mathrm{C} \\
\text { cooling } \\
\text { day }\end{array}$} & \multirow{4}{*}{$\begin{array}{l}\text { Air temp < } \\
0{ }^{\circ} \mathrm{C} \text { (day) }\end{array}$} & Global & 122 & 0.65 & 14.5 & 18.6 & 1.01 \\
\hline & & Europe & 22 & 0.30 & 21.6 & 111.0 & 0.73 \\
\hline & & Asia & 9 & $0.22 *$ & 18.9 & 120.1 & 0.69 \\
\hline & & $\mathrm{N}$ Amer & 91 & 0.71 & 11.6 & -2.7 & 1.08 \\
\hline \multirow{4}{*}{$\begin{array}{l}1{ }^{\circ} \mathrm{C} \\
\text { warming } \\
\text { day }\end{array}$} & \multirow{4}{*}{$\begin{array}{l}\text { Air temp > } \\
0{ }^{\circ} \mathrm{C} \text { (day) }\end{array}$} & Global & 122 & 0.60 & 14.5 & 53.0 & 0.73 \\
\hline & & Europe & 22 & 0.30 & 19.0 & 56.4 & 0.69 \\
\hline & & Asia & 9 & 0.67 & 11.0 & 39.3 & 0.75 \\
\hline & & $\mathrm{N}$ Amer & 91 & 0.58 & 13.3 & 59.2 & 0.68 \\
\hline
\end{tabular}

Table 3 Global and regional linear regression results of $1{ }^{\circ} \mathrm{C}$ phase transition days versus air temperature transition days for non-saline lakes below $700 \mathrm{~m}$ a.s.l, located from $42^{\circ}$ to $69^{\circ} \mathrm{N}$, with surface areas of 100 to $32,000 \mathrm{~km}^{2}$ and depths ranging from $0-680 \mathrm{~m}$

\begin{tabular}{|c|c|c|c|c|c|c|c|}
\hline $\begin{array}{l}\text { Phase } \\
\text { transition } \\
\text { day }\end{array}$ & $\begin{array}{l}\text { Air } \\
\text { temperature } \\
\text { transition } \\
\text { day }\end{array}$ & Region & $\begin{array}{l}\text { Number } \\
\text { of lakes }\end{array}$ & $\begin{array}{l}\mathrm{R}^{2} \\
\text { Adjusted }\end{array}$ & $\begin{array}{l}\text { Standard } \\
\text { error } \\
\text { (days) }\end{array}$ & Constant & $\begin{array}{l}\text { Air } \\
\text { temperature } \\
\text { transition day } \\
\text { coefficient } \\
\text { (days/day) }^{-1} \\
\end{array}$ \\
\hline \multirow{4}{*}{$\begin{array}{l}4{ }^{\circ} \mathrm{C} \\
\text { cooling } \\
\text { day }\end{array}$} & \multirow{4}{*}{$\begin{array}{l}\text { Air temp } \\
<0{ }^{\circ} \mathrm{C} \text { (day) }\end{array}$} & Global & 122 & 0.74 & 9.7 & 48.4 & 0.85 \\
\hline & & Europe & 22 & 0.32 & 13.7 & 166 & 0.48 \\
\hline & & Asia & 9 & 0.61 & 11.5 & 51.2 & 0.85 \\
\hline & & $\mathrm{N}$ Amer & 91 & 0.81 & 7.7 & 18.4 & 0.96 \\
\hline \multirow{4}{*}{$\begin{array}{l}4{ }^{\circ} \mathrm{C} \\
\text { warming } \\
\text { day }\end{array}$} & \multirow{4}{*}{$\begin{array}{l}\text { Air temp } \\
>0{ }^{\circ} \mathrm{C} \text { (day) }\end{array}$} & Global & 122 & 0.80 & 12.7 & 36.8 & 1.05 \\
\hline & & Europe & 22 & 0.30 & 19.5 & 69.6 & 0.71 \\
\hline & & Asia & 9 & 0.82 & 13.2 & -0.2 & 1.34 \\
\hline & & $\mathrm{N}$ Amer & 91 & 0.86 & 9.9 & 34.6 & 1.07 \\
\hline
\end{tabular}

Table $4 \quad$ Global and regional linear regression results of $1{ }^{\circ} \mathrm{C}$ phase transition days versus air temperature transition days for non-saline lakes below $700 \mathrm{~m}$ a.s.l, located from $42^{\circ}$ to $69^{\circ} \mathrm{N}$, with surface areas of 100 to $32,000 \mathrm{~km}^{2}$ and depths ranging from $0-680 \mathrm{~m}$ 


\begin{tabular}{|c|c|c|c|c|c|c|c|c|c|}
\hline \multirow{2}{*}{$\begin{array}{l}\text { Phase } \\
\text { transition } \\
\text { day }\end{array}$} & \multirow[t]{2}{*}{ Region } & \multirow{2}{*}{$\begin{array}{l}\text { No. } \\
\text { of } \\
\text { lakes }\end{array}$} & \multirow{2}{*}{$\begin{array}{l}\mathrm{R}^{2} \\
\text { Adj }\end{array}$} & \multirow{2}{*}{$\begin{array}{l}\text { Std } \\
\text { error } \\
\text { (days) }\end{array}$} & \multirow[t]{2}{*}{ constant } & \multicolumn{4}{|c|}{ Coefficients } \\
\hline & & & & & & 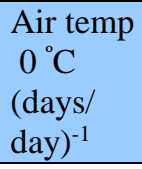 & $\begin{array}{l}\text { Depth } \\
\text { (days/ } \\
m)^{-1}\end{array}$ & $\begin{array}{l}\text { Altitude } \\
\text { (days/ } \\
\text { m.a.s.l.) }\end{array}$ & $\begin{array}{l}\text { Distance } \\
\text { from coast } \\
\text { days/arc } \\
\text { degree) })^{-1} \\
\end{array}$ \\
\hline \multirow{3}{*}{$\begin{array}{l}1{ }^{\circ} \mathrm{C} \\
\text { cooling } \\
\text { day }\end{array}$} & Europe & 22 & 0.51 & 18.1 & 280 & - & 0.761 & - & 6.05 \\
\hline & Asia & 9 & $0.22 *$ & 19.0 & 120 & 0.694 & & - & - \\
\hline & N Amer & 91 & 0.80 & 9.8 & -3.8 & 1.07 & 0.357 & - & - \\
\hline \multirow{3}{*}{$\begin{array}{l}1{ }^{\circ} \mathrm{C} \\
\text { warming } \\
\text { Day }\end{array}$} & Europe & 22 & 0.45 & 16.8 & 161 & - & - & - & -5.52 \\
\hline & Asia & 9 & 0.67 & 11.0 & 39.3 & 0.749 & - & - & - \\
\hline & $\mathrm{N}$ Amer & 91 & 0.65 & 12.1 & 42.8 & 0.722 & 0.176 & 0.0346 & - \\
\hline \multirow{3}{*}{$\begin{array}{l}4{ }^{\circ} \mathrm{C} \\
\text { cooling } \\
\text { day }\end{array}$} & Europe & 22 & 0.46 & 12.1 & 280 & - & 0.461 & - & 3.78 \\
\hline & Asia & 9 & 0.61 & 11.5 & 51.2 & 0.846 & & - & - \\
\hline & N Amer & 91 & 0.85 & 6.8 & 17.8 & 0.948 & 0.202 & - & - \\
\hline \multirow{3}{*}{$\begin{array}{l}4{ }^{\circ} \mathrm{C} \\
\text { warming } \\
\text { Day }\end{array}$} & Europe & 22 & 0.64 & 13.9 & 172 & - & 0.552 & - & -6.18 \\
\hline & Asia & 9 & 0.91 & 9.4 & 10.8 & 1.19 & 0.044 & - & - \\
\hline & $\mathrm{N}$ Amer & 91 & 0.89 & 8.6 & 24.6 & 1.09 & 0.274 & 0.0128 & - \\
\hline
\end{tabular}

* not statistically significant $\mathrm{p}=0.1$

Table 5 Stepwise regression results of phase transition days vs air temperature transition days, depth, lake altitude, distance from coast and lake surface area for non-saline lakes below $700 \mathrm{~m}$ a.s.1, located from $42^{\circ}$ to $69^{\circ} \mathrm{N}$, with surface areas of 100 to $32,000 \mathrm{~km}^{2}$ and depths ranging from $0-680 \mathrm{~m}$ 


\begin{tabular}{|c|c|c|c|c|c|c|c|c|c|c|}
\hline \multirow{2}{*}{$\begin{array}{l}\text { LSWT } \\
\text { Phase }\end{array}$} & \multirow[t]{2}{*}{ Region } & \multirow{2}{*}{$\begin{array}{l}\text { No. of } \\
\text { lakes }\end{array}$} & \multirow{2}{*}{$\begin{array}{l}\mathrm{R}^{2} \\
\text { adj }\end{array}$} & \multirow{2}{*}{$\begin{array}{l}\text { Std error } \\
\text { (days) }\end{array}$} & \multirow[t]{2}{*}{ Constant } & \multicolumn{5}{|l|}{ Coefficients } \\
\hline & & & & & & 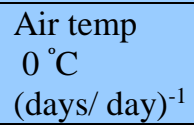 & $\begin{array}{l}\text { Depth } \\
\text { (days/ } \\
\text { m) })^{-1}\end{array}$ & $\begin{array}{l}\text { Altitude } \\
\text { (days/ } \\
\text { m.a.s.1.) })^{-1}\end{array}$ & $\begin{array}{l}\text { Distance from } \\
\text { coast } \\
\text { days/arc degree) }{ }^{-1}\end{array}$ & $\begin{array}{l}\text { Area } \\
\left.\text { days } / 100 \mathrm{~km}^{2}\right)^{-1}\end{array}$ \\
\hline \multirow{4}{*}{$\begin{array}{l}\text { Intervening } \\
\text { cooling }\end{array}$} & Global & 122 & 0.16 & 7.13 & -29.83 & +0.162 & & & & \\
\hline & Europe & 22 & 0.18 & 9.57 & -54.52 & +0.244 & & & & \\
\hline & Asia & 9 & - & - & - & - & & & & \\
\hline & N Amer & 91 & 0.11 & 6.05 & -21.11 & +0.129 & & & & \\
\hline \multirow{4}{*}{$\begin{array}{l}\text { Intervening } \\
\text { cooling }\end{array}$} & Global & 122 & 0.24 & 6.77 & -31.05 & +0.164 & +0.037 & - & - & - \\
\hline & Europe & 22 & 0.42 & 8.09 & -0.17 & - & +0.300 & - & +2.27 & - \\
\hline & Asia & 9 & - & - & - & - & - & - & - & - \\
\hline & N Amer & 91 & 0.28 & 5.44 & -21.57 & +0.124 & +0.155 & - & - & - \\
\hline \multirow{4}{*}{$\begin{array}{l}\text { Intervening } \\
\text { warming }\end{array}$} & Global & 122 & 0.40 & 9.67 & 16.24 & +0.321 & & & & \\
\hline & Europe & 22 & - & - & - & - & & & & \\
\hline & Asia & 9 & 0.85 & 5.26 & -39.47 & +0.593 & & & & \\
\hline & N Amer & 91 & 0.45 & 9.69 & -24.65 & +0.386 & & & & \\
\hline \multirow{4}{*}{$\begin{array}{l}\text { Intervening } \\
\text { warming }\end{array}$} & Global & 122 & 0.47 & 9.02 & -13.06 & +0.328 & +0.037 & -0.019 & - & - \\
\hline & Europe & 22 & 0.36 & 6.20 & +8.95 & - & +0.384 & - & - & - \\
\hline & Asia & 9 & 0.93 & 3.61 & -41.0 & +0.585 & - & - & - & +3.46 \\
\hline & N Amer & 91 & 0.51 & 9.15 & -15.96 & +0.365 & - & -0.022 & - & - \\
\hline
\end{tabular}

Table $6 \quad$ Stepwise regression results of length of intervening phases vs air temperature transition days, depth, lake atitude, distance from coast and lake surface area for non-saline lakes below $700 \mathrm{~m}$ a.s.l, located from $42^{\circ}$ to $69^{\circ} \mathrm{N}$, with surface areas of 100 to $32,000 \mathrm{~km}{ }^{2}$ and depths ranging from $0-680 \mathrm{~m}$ 